\title{
THE IDEA OF THE EUCHARIST
}

\author{
I.
}

I knew how beauty seen from unseen must rise,

How the body's joy for more than body's use was made. I knew then how the body is the body of the mind.

Giordano Bruno, the ex-Dominican, who was burnt by the Inquisition in 1600, said that "the physical universe occupies infinity." This doctrine seems very important for science and philosophy, although Einstein has thrown some doubt on the truth of it, but it is not easy to understand. Does it refer to infinity in space, or in time, or to anything more than that? And what is meant by "occupying " infinity? Does it mean that the physical universe is all that is? If so, then it seems either untrue or meaningless; for thoughts, and hopes, and desires, and resolutions, and emotions, and dreams undoubtedly exist, in some sense of the word " exist," and if the word " physical " is used to include both a dream and a porkpie, then the word has no meaning at all. The "physical universe" is the whole sum of the things whose existence is perceptible by the senses; not thoughts, or spirits, or minds, but matter and energy and their manifestations. For more than a century and a half, since Bishop Berkeley wrote in England and Immanuel Kant in Germany, it has not been necessary to prove that something exists in addition to the things that we can taste and touch, and see, and hear, and smell. The onus of proof is on the other side; the materialist must prove that the physical universe has any existence at all, apart from the minds which perceive it. The important question, as a matter of fact, is not, what does the physical universe "occupy," but what is the physical universe? And most important is the question, what does the physical universe mean? That is the one question about the physical universe which is of interest for religion. The Christian view is rooted in the conviction that the material world exists to be God's means of expressing His mind and heart and will (to speak after the manner of men) to His children, and to be the means in and through which man grows into ever more perfect fellowship with, and likeness to, His Father. "The Laws of Nature are the thoughts of God."

Lord Morley, in the first volume of his Recollections, says that the last half of Book IV. of Wordsworth's "Excursion" is " among the finest things in great poetry. It is real religion." 
There Wordsworth, with the poet's insight (which is not a special faculty that plain men do not possess, but is the insight of a man when he is most nobly and freely human, the insight of each one of us when he stands at the great experiences of life), shows what the world is, and is intended to be.

A curious child, who dwelt upon a tract
Of inland ground, applying to his ear
The convolutions of a smooth-lipped shell;
To which, in silence hushed, his very soul
Listened intensely; and his countenance soon
Brightened with joy; for from within were heard
Murmurings, whereby the monitor expressed
Mysterious union with its native sea.
Even such a shell the universe itself
Is to the ear of Faith; and there are times,
I doubt not, when to you it doth impart
Authentic tidings of invisible things;
Of ebb and flow, and ever-during power;
And central peace, subsisting at the heart
Of endless agitation. Here you stand,
Adore, and worship, when you know it not;
Pious beyond the intention of your thought;
Devout above the meaning of your will.

Any study of Nature carried on in final separation from some such view as this, any selfish probing of her mysteries merely in order that man may have power over her, or curious dissection of her dead body as though that were all, reveals its fundamental untruth by the fact that it degrades man instead of making him better, "waging an impious warfare with the very life of our own souls." The naturalism which banishes the thought of God and the soul when it attempts to understand the world (assuming that the spiritual element in things is what man puts into them, as though the material manifestation were not due to spiritual reality*) inevitably comes to think in terms of force, without any reference to the spirit, and (though perhaps unintentionally) without reference to conscience. That is the intellectual method which has laid Europe in ruins, and has secured that all the resources of modern science should be used to perfect engines of destruction, so that the large howitzer and the high-explosive shell are the characteristic products of modern civilization. That is the meaning of Rabelais' saying that science without conscience is damnation. Earth without God is a degrading and unsatisfying deception.

The physical universe is permanently an inspiration and comfort and discipline to a man only when, quite definitely, it is the means of his fellowship with God. The vague sentimental nature-worship of the spring poet gives a delusion of nature's sympathy, while men are willing to be deluded. It is only when they experience the natural world as the means by which the

* Alice Gardner, History of Sacrament in Relation to Thought and Progress, p. 173. 
Father of spirits reveals Himself, that men find real courage and strength in contact with nature. Francis Thompson has put into moving words the truth that the physical universe is a sacrament. "The Supreme Spirit, creating, reveals His conceptions to man in the material forms of Nature.... An ideal wakes in the Omnipotent Painter; and straightway over the eternal dikes rush forth the flooding tides of night, the blue of Heaven ripples with stars; Nature, from alp to alpine flower, rises lovely with the betrayal of the Divine thought. An ideal wakes in the Omnipotent Poet; and there chimes the rhythm of an ordered universe. An ideal wakes in the Omnipotent Musician; and Creation vibrates with the harmony, from the palpitating throat of the bird to the surges of His thunder as they burst in fire along the roaring strands of Heaven. ... Earthly beauty is but heavenly beauty taking to itself flesh."* "Our earthly city is the body of the city of God." The fact that these are the words of a poet, and that he mentions only the pleasant things in the physical universe, does not mean that the sacramentalism of nature is only an idle fancy. The loss and pain and waste in the world, and the possibility of sin and moral ruin, are tolerable on the assumption that they are the expression of God's creative will that men should, in the use of and conflict with these things, win the freedom and perfect personality in which alone they can enjoy equal fellowship with God. Law and destiny and nature exist to reveal God to man, and to discipline man, by that revelation, to become a person like God. "He that overcometh," says the Risen Christ, "I will give to him to sit down with Me in My throne, as I also overcame, and sat down with My Father in His throne" (Rev. iii. 21).

The physical universe is rightly understood, and possessed, and used, only when it is found in God and God in it. Even the gloom and darkness are the "shade of His hand, outstretched caressingly." But this must not be taken to mean that it is only in the whole, the all, the immensity of the infinite physical universe that God is revealed without misrepresentation. The experience of life, and one of the central thoughts of Christianity, is that the true meaning and highest value of the world is revealed not in the whole, but in particular things; not in crowds or mobs, but in definite persons; not in generalities, but in particulars. It has been said that " the individual is the true universal." It is certainly true that the God who reveals himself in humanity, revealed Himself especially and adequately in one human life. Jesus Christ was the light which lighteth every man coming into the world.

* "Nature's Immortality": The Works of Francis Thompson, vol. iii., pp. 86, 87. 
It is remarkable that our Lord, who founded a world religion, never left His own land, and once stated, quite without reservation, that He was not sent save to the lost sheep of the house of Israel. The key to the apparent contradiction is the story of the Good Samaritan. He had been asked, "Who is my neighbour ?" He did not say, as a modern philanthropist might, "Everybody." He said, "The man whom you come across on your journey, who needs your help." We can only do our duty to humanity by doing it to the particular men and women who are part of our own lives. So He loved those whom He $\mathrm{knew}$, and preached to His own people. There is a persistent weakness of heart and head which talks about the Brotherhood of Man and is ill-tempered and selfish in the family circle. But it is of the greatness of true love that it is individual; that it gives itself, for ever, to one person; as it is of the nobility of patriotism that it can count all the world well lost for the sacred earth of one small land. The suggested communization of women and children is not really a more spiritual conception than that of the Holy Family. Apart from particulars, the general is a mere word. Men can only find the all in the some.

There are broad-minded people who seek, above and behind Buddhism and Islam and Christianity, the eternal and absolute truth of which each positive religion is a poetic and popular presentation. Is it not probable, they argue, that the infinite and eternal God will manifest Himself to, and through, the soul of every people, so that each from its own standpoint can mirror one aspect of the Infinite, and all together reveal Him as $\mathrm{He}$ is ? That is what might be expected, and, indeed, the idea is not without truth and value. But as a matter of plain historic fact it is to one nation, the Hebrews, that the human race is indebted for its faith far more than to all the others together. When God revealed Himself to humanity, that man might win at last assurance of the Divine in the human and of the Divine through the human, then, as Mr. Chesterton has put it, He spoke to all men of every race through chosen individuals of a chosen race.

In the same way, the sacramental meaning of the whole of nature and life is consummated and brought to full and explicit expression, and not denied or minimized, by the special sacraments used by Catholic Christians. Pious Protestants sometimes find in their vivid consciousness of the spiritual reality of all nature, and of the divine purpose revealed in all life, a strong argument for doing without special sacramental means of grace. Other Christians, impressed by the truth that the real sphere of religious duty is the common life of every day (so that reconciliation with God is found in a willing acceptance 
of God's providence, and in a glad undertaking, as being God's will for us, of the responsibilities and tasks of what is called secular life), fear lest any expectation of special grace in such purely ecclesiastical means as the Sacraments should issue in a separation of religion from life, as though God and His grace are active for our salvation on Sundays in church, and the life of service and adventure and fellowship which is the main concern of all men were without significance for God. But this life, with its warfare and its duty, is a part of eternity; in its opportunities and obligations God is revealed, and His will and His succour. Unless His grace is there, it is nowhere that matters for us. But the general and the special are not opposed; rather do they give meaning to each other. The fact that all life ought to be a fellowship with God is apt to be forgotten unless we make and use special opportunities to make definite and explicit our consciousness of that fellowship, and its meaning for duty and life. Centuries of Christian thought and idealistic speculation have made familiar the idea that God is everywhere. In church, on the hillside, in the thronged marketplace, in the hospital ward, in the battle-field, God is everywhere. And for most men there is hardly any difference between "God is everywhere" and "God is nowhere." There is real danger that the man who insists on his communion with God in nature taking the place of His communion with God in church (instead of helping and being helped by it) will either become a mere creature of his moods, or forget who made the flowers and the sunset for His own delight. The man who is so sure that God is in the market-place that he never goes to seek Him in church seems complacently over-confident of his own spiritual insight. "It is quite possible," says Miss Gardner, * " that a glib acquiescence in the statement that "all life is sacramental 'might encourage such a process of secularization as to leave no scope for the recognition of spiritual values." Jesus of Nazareth, who found in nature and in human life a revelation of His Father's love, and a true means of grace, also joined in the fellowship of the synagogue prayers and of the temple sacrifices. The Eucharist, especially, makes the Divine Presence concrete and particular. We must find the meaning of life and duty in the sacrifice and communion of sacramental worship, and the former must give spiritual reality to the latter. The one is not a rival to the other, but rather its inspiration and symbol and explanation.

Baron F. von Hügel has given an impressive statement of the place in Christian thought of the individual and particular. In a letter to Father Tyrrell he says, " Blondel is surely right at

$$
\text { * Op.cit., p. } 96 .
$$


least where he says that the true Absolute and Universal springs for us from the true Concrete and Particular; God, I like to think with Lotze, is the supremely concrete, supremely individual and particular; and the mental and practical occupation with the particular must ever remain an integral part of my way to Him. And this squares so grandly with the whole sacramental doctrine and practice of the Church. One gets otherwise into a Neo-platonic depersonalizing of the soul."* But this fundamental Christian concern with the individual and particular finds its supreme expression in the Incarnation. All the fullness of the Godhead bodily was revealed in a particular human life. God who is immanent in humanity was incarnate in Man. At a particular moment in time, and at a particular place, in Palestine nineteen hundred years ago, God took hold of humanity in a new, definite, recognizable, unique fashion. The "idea" of the Eucharist is the same as that of the Incarnation. They imply the same method. As St. Justin Martyr put it in the middle of the second century, "we have been taught that the food which has been blessed by the invocation of the Word that is from Him . . . is the flesh and blood of that Jesus who was made flesh." $†$ At a definite time, at the time of consecration, in a definite place, on the altar, the Word becomes incarnate again, that in a Sacramental Body He may be present to inspire and uplift, to challenge and strengthen, to make humble and make brave, those who have given themselves to $\mathrm{Him}$, to live for the things for which $\mathrm{He}$ lived. In the Sacraments-and the Eucharist is the type-God who in and through the whole physical universe disciplines, and has fellowship with, and gives Himself to, men, does specially, and in what one may call an obviously personal way (for personality is usually revealed in what is unique and particular, rather than in the general and universal), give Himself to His children. The life of mankind misrepresents, almost as much as it reveals, the God who is its source and its goal; but the whole meaning of the life of Jesus is God. So nature, with its cruelty and waste as well as its beauty and law, is a veil drawn over the face of God; but the Sacraments respond to man's need for " some pure untroubled element which has no significancy except as the organ through which the voice of God speaks to man "; $\ddagger$ they have no meaning unless they are the means which God has appointed§ by which men may have fellowship with Him and lay hold on the eternal order.

* George Tyrrell's Letters, p. 44.

† First A pology, chapter lxvi. Dr. Waterman's translation.

‡ F. D. Maurice, The Kingdom of Christ (edit. 1883), vol. ii., p. 87.

$\S$ In St. Augustine's phrase they are signa data, not naturalia; res and signum are arbitrarily conjoined (De Doctr. Christ. ii. 1) 
It is, then, no mere accident of history that the Sacraments are rooted in the Incarnation, that they are, as the catechism puts it, "ordained by Christ Himself." Neither is it a mere trick of the human mind which brings about (what undoubtedly occurs) that an a-sacramental or anti-sacramental religion inevitably tends to Unitarianism. The Sacraments are "the extension of the Incarnation."

II.

All earth is a parable, and a miracle as well.

"That is not first which is spiritual, but that which is natural." From the necessities of human development, the spiritual has to be expressed in thoughts and words, whose origin and customary reference belong to the external and material world. In many languages, for example, the original meaning of the word used for "spirit" is "breath." That means that religion is always partly inarticulate. The ideal eludes analysis, and even the truest and most adequate definition of the Divine half conceals, even if it half reveals, the ineffable Reality. The truth of dogma is "symbolic " or " prophetic," to use Tyrrell's words. Professor J. B. Pratt, in his great book on The Religious Consciousness, quotes "A Catholic priest" as saying: "Dogmas are a kind of intellectual sacramentthat is, intellectual and imaginative signs of realities that are supra-intellectually cognized by the deep dim intuitive apprehension of faith; and they well may be called a kind of sacrament, for they are effectual signs - that is, they tend to generate or elicit, in the mind which receptively apprehends them, that very vision of faith which they so inadequately express and attempt to communicate."* All speech about the spiritual world must be non-literal; it is not, therefore, fanciful, or imaginary, or unreal. $\dagger$ God always speaks to His children in symbols, metaphors, allegories, or parables; but the symbol is more true, not less true, than any attempted exact definition. The Incarnation itself is a parable or symbol of God's love for, and desire to touch, the world; and the Eucharist is the parable or allegory of a more unrestricted activity of redemption than was possible in Galilee and Judæa. $\ddagger$ When Jülicher called the Eucharist an " acted parable" he was stating a great truth. The Lord's Supper and the Lord's parables illuminate each other.

It was fitting that He who was the Incarnate Word should

* Pratt, op. cit., p. 206. p. 168.

$\dagger$ Cf. L. Waterman, The Primitive Tradition of the Eucharistic Body and Blood, ‡ Waterman, op. cit., pp. 61, 72. 
clothe His message in terms of actual life. He shows the ideal taking shape in the common relations of every day, the eternal embodied in "the trivial round, the common task." Not in terms of intellect, but in terms of nature and humanity, $\mathrm{He}$ shows us God. The heart of Christ's message is bound up with the reason why He used fishing-nets, and lost sheep, and patched coats, and women sweeping their houses, as the means by which He brought home the truth of God to the will and conscience of men. He made these concrete, commonplace things symbols of the eternal, sacraments of grace and light. The words that He spoke are pictures, and that is one reason why they are spirit and life. These glimpses of real humanity shining with the glory of an ideal divine meaning are part of the same revelation as the Incarnation, where humanity becomes most Divine, and God becomes most human, and as the Eucharist, where bread and wine become the channel and instrument of His Mystical Presence. That is why, "without a parable He spake nothing unto them: that it might be fulfilled which was spoken. . . I I will utter things hidden from the foundation of the world."*

The parables are religion, not theology. They spring out of the vital, continuous experience of the Father which was the background of all Christ's life, the context of every word that He spoke, the motive of every action, the home in which He was at peace. And if men can stop analyzing the parables, or trying to explain them, or moralizing about them, if they will only yield themselves in simplicity to their simple appeal, they will feel the deep things of the spirit, and what is too real for words will remind them that it will not be ignored. God ceases to be the conclusion of an argument; He is an Experience, a Friend. The strange hopes and shames of the spirit of man are clothed, not in logical statements, but in living, breathing flesh. Windows are opened into heaven. These stories move men to penitence and hope. The reality of religion is in them. They touch the deepest and most real in every man, not the mind alone, not the emotion alone, but the very springs of motive, the sources of action. Much religious instruction (all theorizing and theology, and nearly all moral exhortation) fails just here. It cannot purify the motives, it cannot change the will, it gives no power $t_{0}$ realize the ideals it expounds. But just in so far as men yield to the appeal and influence of Christ's parables, they will find this obstinate inward conflict reconciled. "The Word became Flesh," and all His teaching has the completeness, the intimacy, the tangible vitality of the living Humanity which is body and spirit as well. The In-

* St. Matt. xiii. 34, 35. 
carnate Word spoke nothing without a parable. This throws fresh light on the Holy Eucharist, which is in some sense the greatest of all parables, and is also really the extension of the Incarnation. When $\mathrm{He}$ blessed the Bread and the Wine $\mathrm{He}$ was declaring things hidden from the foundation of the world.

At the Holy Table men and women are admitted to religious experience at its most simple and most exalted, in its least intellectualized, aspect. This is not talk about religion, but the spiritual reality itself; the Shepherd leads us in green pastures, and by the waters of peace. All that the most eloquent preachers have tried in vain to describe, all that theology seeks to explain and rationalize, the Reality which the beauty of a noble church hints at, the mystery of the altar cross and the lights and the silence of adoration, the Presence that children can feel and the wisest cannot understand, the Fellowship that makes the proud ashamed and sends the selfish out to serve his brethren and the worldling to seek for the things that are not seen-the mystic channel of this Divine experience is through the consecrated elements, the Bread and the Wine that Christ uses for the comfort and sustenance of His own.

Christ has taken common everyday things and made them channels of grace. "This exaltation of the homeliest act of life to its great spiritual significance," Miss Gardner points out,* " is an illustration of the greater appeal to the heart made by symbol than by what seems to have no mystery about it." This is the meaning of His life, that ordinary things are divine, that simple things are like God, that wild flowers are more glorious than the pomp of a king's court, that boys and girls play in the streets of the City of God, that the Son of God wore a workman's coat, that a fisherman may be His apostle, that every supper-table may be the Table of the Lord, that all earthly things are meant to reveal the spiritual, and eternal, and divine. That is why they are here. "All meals are sacraments, really," says C. E. Montague, $\dagger$ " only some vulgarization of them, or of us, repels us at most times; we cannot communicate." Christ has consecrated, made divine, what men have vulgarized. The material things which they have debased and degraded, He uses for the praise of God. The food that men eat so carelessly, so wastefully, so ungratefully, so wickedly, becomes the Body of the Lord; the wine they have drunk so thoughtlessly becomes His Blood. So Love redeems the material universe.

Christ did a dangerous thing when He took bread, and gave it to His disciples, and said, "Do this in remembrance of Me." He asked men to eat together as a token of fellowship. From

* Op.cit., p. 46.

$\dagger$ The Hind Let Loose. 
one point of view, that is in the broad human tradition. Men have always feasted together as a mark of friendship. But the Lord Jesus was an Oriental, and in the East this matter of eating together is surrounded by all sorts of ancestral tabus and ancient jealousies and fierce contempts and obscure racial antagonisms. How careful an Arab is before He will eat salt with a man! And the nerve of brotherhood is cut by all that is summed up, in India, in the word " caste," and the casterules are in nothing more obtrusive than in this matter of eating with others. Christ was provoking wild prejudice and hatred when, as a sacref an remeral religion, He put a common meal. There were once sharp words between great apostles on this very question of eating in common.* The fellowship of the Church is founded in divisions transcended, in ancestral tabus deliberately broken, in an appeal to the one blood of all the nations of the earth. He uses the occasion of strife as a sacrament of communion.

But if the Bread was dangerous, it is almost impossible to realize the social and religious whirlpool into which the Lord Jesus launched the disciples when He said, "This is My Blood." The very thought of drinking blood sends a shudder of horror through every normal human being. The foulest stories were told, indeed, in Rome during the early centuries about the blood-drinking at Christian meetings. Among the Jews this instinctive horror becomes definite and explicit in the demands of their religion. And, as though there were not enough of danger and prejudice here, it was wine that Christ consecrated to be His Blood. Wine makes glad the heart of man, and brings sadness and poverty. Wine is the symbol of fellowship and hospitality, and the occasion of quarrelling and strife. Wine uplifts, and casts down into brutishness and devilry. Wine that is a temptation (there are few more dangerous) Christ makes into a sacrament. Men will not face this paradox. They water it down, and explain it away. It has been suggested that it was not fermented wine that He used. But this is a gratuitous assumption, for which there is not a shred of evidence. The Lord Jesus was called a wine-bibber, a jibe that would have been impossible unless He had been in the habit of drinking intoxicants. Or, more reasonably, people say that wine was not the temptation in that country, and at that time, that it is here and now. But all the evidence points in the opposite direction. The Old Testament and the New have many references to the evil of drunkenness, and to the temptation of strong drink; and not even in the Bible do preachers denounce evils, and warn against temptations, which are not real for their

* See Gal. ii. $11 f$. 
audience. Moreover, Latin writers of the first and second centuries have left descriptions of drunkenness and debauchery unsurpassed in the world's literature. However difficult it may be to understand, the fact stands out clearly that Christ took this thing which might almost be called the prototype of all temptation, and made it into a sacrament. There is nothing so dangerous, so fraught with possibilities of destruction, so intimately associated with the worst passions and indulgences of frail humanity, that Jesus Christ cannot consecrate it, and use it, and make it a positive, redeeming, strengthening element in human life.

That the Holy Eucharist is the expression and confirmation of the implicit sacramentalism of the visible world also becomes apparent from its relation to the pagan mysteries, at Eleusis and elsewhere. The Eucharist is the "Christian mysteries," without which the Græco-Roman world would hardly have considered the Church a religion at all.* The word sacramentum first appears in Christian use, not primarily to mean a soldier's oath, but as the translation of the Greek $\mu v \sigma \tau \eta^{\prime} \rho \iota \nu, \dagger$ and early apologists recognize the similarity between the pagan and Christian services, for they stigmatize the pagan mysteries as counterfeits, constructed by demons in imitation of the Holy Eucharist. $f$ There is abundant evidence that the development of Christian doctrine, as early as the Apostolic age and as late as the middle of the third century, was much influenced by the practice and vocabulary of the mystery religions, which proved to be an important preparatio evangelica. As it was sacrilege for an initiate to divulge the secrets of the "mystery," many points about them are still obscure. But the essence of the mystery seems to have been that after moral and ceremonial purification, $\S$ the initiate was admitted to see enacted a dramatic representation which made clear the symbolic meaning of the life of the god. At Eleusis, for example, was presented in symbols the story of Demeter and Persephonell (by the former of whom the mysteries were said to have been instituted), a story in which nature symbolism was very near the surface. "Processes which ever repeat themselves in nature, and by the repetition of which we live; processes behind which is God were represented as the movement of the Divine life, represented by a procession of symbolic acts and words."' And then the worshipper was allowed to handle the Divine

\footnotetext{
* A. Loisy, The Gospel and the Church, p. 226.

† T. A. Lacey: Article "Sacraments, Christian (Western)," Encyclopcedia of Religion and Ethics, vol. x., p. 903.

$\ddagger$ Tertullian, De Proescr. 40.

$\S$ Miss Jane Harrison derives $\mu \nu \sigma \tau$ j́p to Greek Religion.

II Walter Pater, Greek Studies, p. 122.

ป G. A. Johnston Ross.
} 
symbols, and at last to taste them. He asserted as his own the Divine life. "The mystery was an acted parable of the relation of the spirit of man to the Divine basis of the world."* In its more developed form, the mystery aimed at being a religion of salvation, an "effectual sign" of union with a God who shares the life of man, asserting such a Divine interest in a man's affairs as would sustain him through the difficulties of life, developing and emphasizing his hope of immortality, and giving the only clear statement in Greek popular religion of the idea of personal holiness.

The Holy Eucharist, then, is fitly called " these holy mysteries," not because it is vague, sentimental, other-worldly, but because it is a channel of union with God, a drama of the life of God, and an assertion of the believer's oneness with Him. It is hardly an exaggeration to say that no thought has been more closely associated with the Eucharist than the hope of immortality. Ignatius called the Lord's Supper " the medicine of immortality," and this connection doubtless goes back to the great sixth chapter of St. John's Gospel. They who eat Christ's flesh and drink His blood have eternal life (St. John vi. 54). They become one with that which they partake.

Tertullian calls the Eucharist " the theatre of the pious," and the movement of the liturgy represents the successive stages of Christ's self-offering; it is " the story of the actual career of Jesus, told as it were in holy pantomime." $\dagger$ At the oblation of the elements He offers Himself in Gethsemane; at the consecration His Body is broken and His Blood shed; at the "commixtio" His Resurrection is recorded, so that it is the crucified and living Christ on whom His worshippers are fed. $\ddagger$ All the meaning of the life of Christ, all its Divine revelation, is summed up here, in a broken Body and Blood shed. Death, self-giving, love-these are the life of God. Eating, men say, "I and my Father are one," one in will, one in purpose. They pledge themselves to the ideal which the mystic expressed in the words, "I am Thou and Thou art I."

\section{A. E. BAKER.}

* P. Gardner : Article "Mysteries (Greek)," E. R. E., vol. ix., p. 77.

$\dagger$ Evelyn Underhill, The Mystic Way.

$\ddagger$ W. H. Frere, Principles of Religious Ceremonial, chap. ii.; Neale and Little. dale, Liturgies of SS. Mark, James, and Clement, pp. xxi.-xl.; and a full bibliography in Hirn, The Sacred Shrine. This view of the prayers and ceremonies of the Mass was common in the Middle Ages, and is found in a MS. prepared by the commission, appointed in 1540, which issued The King's Book. See Darwell Stone, $A$ History of the Doctrine of the Holy Eucharist, vol. ii., p. 120.

(To be concluded.)

III. 18 